\title{
Plan writing as a policy tool: instrumental, conceptual, and tactical uses of water management plans in California
}

\author{
Nataly Escobedo Garcia ${ }^{1}$ Nicola Ulibarri ${ }^{2}$ (i) \\ Accepted: 31 January 2022 / Published online: 24 February 2022 \\ (c) The Author(s) 2022
}

\begin{abstract}
Numerous environmental regulations require organizations to codify prospective activities in a written plan. However, evidence suggests that many plans are never implemented, raising questions about why public agencies continually require plans, whether mandating plans allows agencies to meet their policy aims, and what additional purposes plans serve. Adopting concepts from literature on research utilization, we develop a plan use typology, defining instrumental use as occurring when the requirement to write a plan directly addresses a stated policy problem, conceptual use as occurring when the requirement to write a plan indirectly addresses a policy problem by raising awareness of an issue or improving governance capacity, and tactical use as occurring when the requirement to write a plan serves a political or symbolic purpose unrelated to solving the policy problem. We then apply the typology to four California statutes that require local and regional utilities to write water management plans. We first assess the statutes to identify the goals underlying the requirement to write a plan and assess what plan uses are emphasized in guidance documents and the written plans themselves. Lastly, we interview the plan writing organizations to capture their perspectives on the value and limitations of these plans. We find that legislators turn to plans to support instrumental and conceptual goals but that the plans themselves and the way they are used by authoring agencies primarily serve conceptual and tactical uses, suggesting a disconnect between the policy goals underlying plans and their actual use.
\end{abstract}

Keywords Water resource management $\cdot$ Water resource planning $\cdot$ California $\cdot$ Plan evaluation

\section{Introduction}

The plan is a ubiquitous policy tool, especially in the environmental space. From shoreline management plans, to drought contingency plans, to recreational management plans, numerous environmental regulations require that organizations codify their prospective policies and programs in a written document. In some cases, laws require government agencies to develop internal plans to guide their actions, as when the National Forest Management Act requires the US Forest Service to develop plans to guide management of all their landholdings. In other cases, agencies require other public, private, and non-profit

Nicola Ulibarri

ulibarri@uci.edu

1 School of Social Ecology, University of California Irvine, Irvine, CA, USA

2 Department of Urban Planning \& Public Policy, University of California Irvine, Irvine, CA, USA organizations to write plans in order to comply with permitting requirements (e.g., the Endangered Species Act requires applicants for an incidental take permit to write a Habitat Conservation Plan), qualify for funding (e.g., FEMA's Hazard Mitigation Grant Program requires local governments to have an approved hazard mitigation plan to qualify for disaster funding), or as a requirement for operating in a jurisdiction (e.g., the State of California requires local governments to draft and update General Plans to guide community activities).

The ubiquity of requirements to write plans belies the fact that existing literature suggests that plans are rarely implemented. The written plans themselves often conform to baseline requirements but lack details that would support their implementation (Norton 2005; Berke et al. 2006; Bunnell and Jepson 2011; Woodruff and Stults 2016; Horney et al. 2017; Ulibarri et al. 2021). Many external factors further limit plan implementation (Laurian et al. 2004; Kinzer 2018; Feinberg and Ryan 2020), including a lack of funding or leadership (Feinberg and Ryan 2020), changes in personnel 
(Scott et al. 2020), a lack of political will (Kinzer 2018), and a lack of consequences for nonimplementation (Laurian et al. 2004). Taken together, these challenges mean that plans often simply sit on a shelf (Shepherd 1998).

Moreover, public agencies have numerous alternative tools they could use to achieve their goals. Instead of requiring organizations to write a plan, governments could shape the behavior of regulated entities through direct regulations, deploying economic instruments, or engaging in capacity building (Taylor et al. 2012). Yet, in many environmental settings, they continually turn to plan writing as a (if not the) central policy tool.

With this backdrop, critical questions are why governments require plans and what purposes they serve. This paper asks whether plan writing requirements serve an instrumental, conceptual, or tactical purpose. Adopting concepts from literature on research utilization (Weiss 1979; Beyer 1997; Amara et al. 2004), we define instrumental use as occurring when the requirement to write a plan directly addresses a stated policy problem, conceptual use as occurring when the requirement to write a plan indirectly addresses a policy problem by raising awareness of an issue or improving governance capacity, and tactical use as occurring when the requirement to write a plan serves a political or symbolic purpose unrelated to solving the policy problem.

Traditional views of plan quality focus on a plan's instrumental use-its implementability and ability to achieve policy objectives (Brody 2003; Berke and Godschalk 2009; Horney et al. 2017). However, plans exist in a broader institutional context, and policymakers may have other motivations for using plans. In this paper, we evaluate the goals policymakers have when they issue a requirement to write plans, whether the plan is an effective vehicle to achieve these goals, and how the agencies that author the plans actually use them. We assess these questions using a mixedmethods evaluation of water management plans in California's Central Valley. We first evaluate statutory requirements to write plans and associated guidance documents to identify the goals agencies envision, what they require, and how they support those goals. We then compare the content of the plans to the original policy guidance, to see how the policy vision is translated into the written document. Lastly, we interview water managers from the plan writing organizations to understand how the plans are used and to capture their perspectives on the value and limitation of these plans.

\section{Literature review}

Planning theory highlights numerous instrumental benefits for using plans. Planning provides a systematic approach to achieving policy goals; it entails identifying and describing a problem, identifying potential approaches to solve that problem, and selecting from among the identified alternatives (Randolph 2011); the resulting work is then codified in a written plan. Many plans provide detailed descriptions of a geography and/or problem, detail specific policy or management approaches, and sometimes lay out steps for implementation (Preston et al. 2011; Ulibarri 2015). Additionally, while the exact legal obligations vary by plan, the organizations that produced those plans are perceived to be accountable for the actions they lay out, and plans can help these organizations mobilize resources toward these actions (Siders 2017). Thus, as long as the plans' aims are aligned with the goals of the regulatory agency that required the plan to be written, writing a plan should help the agency achieve their aims.

Requiring plans may also provide conceptual benefits of broadening general governance capacity. First, the act of writing a plan - the planning process - can help organizations set visions and goals, identify gaps in knowledge, and understand risk (Neuman 1998; Innes and Booher 2003; Siders 2017), further supporting decision-making in complex settings (Hopkins 2001). Planning also can encourage collaboration and create ownership and buy-in to the final document (Innes and Booher 2003; Siders 2017; Cravens et al. 2021). Second, when a central government agency requires local governments, businesses, or nonprofits to write plans, it creates a setting where similar activities can be implemented across multiple jurisdictions. If paired with a transfer of knowledge across local jurisdictions, planning creates the possibility for a polycentric governance system that enables experimentation, learning, and diffusion of risk across the individual units of the system (Ostrom 1999, 2010; Andersson and Ostrom 2008).

Finally, plans may be used tactically. Plans are political tools. Choices about what to include in plans and what to omit (whether made by the agency requiring the plan or the organization writing the plan) reflect specific political agendas, not an objective view of a policy problem (Forester 1980). Additionally, plans can serve as signals, highlighting that an organization is active in a policy space or signaling credibility-even without intention to implement the proposed activities (Siders 2017; Hopkins and Knaap 2018). In settings where a policy objective is politically unpalatable, policymakers may opt for a policy tool that is less controversial (Keohane et al. 1996; Gilligan and Vandenbergh 2014). As requiring a plan is less invasive than direct regulation, it may be seen as a relatively lowhanging fruit. In some cases, plans might actually dilute or distract from more effective regulation, if decision-makers consider the policy problem "solved" because of the plan requirement and do not pursue additional regulation (Dunn 2017). 


\section{Planning requirements in California water management}

In this paper, we explore whether water management plans serve instrumental, conceptual, and/or tactical purposes, using the case of water management in California. Facing increasing environmental pressures like prolonged droughts, aquifer depletion, extreme wildfires, and sea level rise, California has issued numerous regulations to protect its resources for future generations (Vogel 2018), many of which use natural resource planning as an approach. The state has a large scope of required plans, from shoreline management plans to drought contingency plans, as well as many incentivized-but-not-required plans like climate action plans. The large sample of environmental regulations in California that require organizations to codify their prospective policies and programs in a written document makes it a quintessential case study for understanding the purpose and effectiveness of plan writing as a policy tool.

We focus specifically on the water sector, which is arguably one of the most contentious and "wicked" environmental sectors in the state (Hanak et al. 2011). We view this as a "critical" case (Flyvbjerg 2006) wherein planning is expected to work relatively well. Relative to many contexts, California water has a long history of using and requiring plans, and there are multiple legislative requirements targeting a variety of water users. This paper analyzes four water management statutes: the Urban Water Management Planning Act of 1983, the Regional Water Management Planning Act of 2002, the Water Conservation Act of 2009, and the Sustainable Groundwater Management Act of 2014. These statutes are all primarily administered by the California Department of Water Resources (DWR). In each of these statutes, the requirement to write a plan is the core policy tool used to achieve legislative objectives. These four statutes require the production of four distinctive water management plans: Urban Water Management Plans (UWMPs), Integrated Resources Management Plans (IRWMPs), Agricultural Water Management Plans (AWMPs), and Groundwater Sustainability Plans (GSPs). Besides their central use of plans, these four statutes were also selected because they focus on the most critical sectors of water management in California and target broad sectors of water users, including both traditionally conservative agricultural water agencies and more progressive urban agencies.

The Urban Water Management Planning Act (UWMPA) of 1983 (Assembly Bill or AB 797) aims to secure the conservation and efficient use of urban water supplies. UWMPA targets any publicly or privately owned water suppliers providing water for municipal purposes to more than 3,000 customers or supplying more than $3,000 \mathrm{ac} f \mathrm{tt}$ of water annually. It requires these suppliers to draft Urban Water Management Plans (UWMPs), which are updated on 5-year intervals.

The Regional Water Management Planning Act of 2002 (Senate Bill or SB 1672) established a framework for encouraging local agencies within a region to coordinate in managing water supplies, water quality, and flood protection. It requires regional water management groups to prepare and adopt Integrated Regional Water Management Plans. State agencies, primarily DWR, act as partners to the regions, developing principles for advancing the regional plans and criteria for distributing water bonds.

The Water Conservation Act of 2009 (SB X7-7) aims to encourage efficient water use by the urban and agricultural sectors. A subsection, titled the Agricultural Water Management Planning Act (AWMPA), requires agricultural water suppliers serving more than 25,000 irrigated acres (excluding recycled water deliveries) to submit an Agricultural Water Management Plan (AWMP) to DWR. These plans must include reports on the implementation status of specific Efficient Water Management Practices. The AWMPA sets goals and deadlines regarding when the implementations must occur and, in an attempt to encourage compliance, makes water suppliers ineligible for state water grants or loans unless certain terms have been met.

The Sustainable Groundwater Management Act of 2015 (AB 1739, SB 1168, and SB 1319) is the first statewide law governing groundwater. Under SGMA, water users who share a groundwater aquifer are mandated to create Groundwater Sustainability Agencies (GSAs); these GSAs are required to develop and implement Groundwater Sustainability Plans (GSPs), 20-year plans that define a standard for sustainable groundwater management and use and determine how the GSA will achieve that standard.

\section{Data and methods}

To assess whether water management plans serve instrumental, conceptual, and/or tactical purposes, we evaluate the rationales and performance of plan requirements at several stages of the policy process (Table 1). First, having selected a particular policy tool, the legislature provides their goals for the legislation and justification for the choice of tool; we evaluate whether legislative justification matches a more instrumental, conceptual, and/or tactical aim. Second, once the legislation is passed, the implementing agency (in this case, DWR) provides guidance to water utilities required to write plans; in the guidance, they may highlight instrumental, conceptual, and/or benefits of the plans. Third, local water utilities write the plans; depending on whether they conform to requirements and the level of detail they provide, 
the content of the written plans may suggest their utility for instrumental, conceptual, and/or tactical purposes. Finally, the plans may have various impacts on decision-making; if they are implemented directly, it suggests instrumental use, whereas indirect governance or political benefits suggest conceptual or tactical use, respectively. Importantly, a plan can fulfill multiple uses, both within and across policy phases.

We apply inductive discourse analysis to the aforementioned statutory requirements, their associated guidance documents, and a sample of the resulting plans (Table 2). For each of the four statutes, we first identified the main goals of the statutes, the rationale for requiring plans (if available), and the intended purpose of the planning documents; the entire statutes were reviewed. We then analyzed relevant guidance documents to identify how they translated legislative requirements for plan preparing entities and what goals they articulated and analyzed the written plans themselves to see how well they conformed with the legislation and guidance and what features of the plan or process they highlighted.

As all plans are updated at regular intervals (often five years), we assess only the most recent round of submissions at the time of data collection: 2015 for URWMPs, 2013 for IRWMPs, 2015 for AWMPs, and 2020 for GSPs. Because the guidance and specific plan requirements have changed over time, by focusing on the recent plans, we ensure that we capture interpretation and implementation of the most recent plan requirements.

While there are dozens (in the case of IRWMPs, GSPs, and AWMPs) to hundreds (in the case of UWMPs) of each plan type across California, we selected representative plans from water providers in California's Central Valley. The Central Valley is a microcosm of water governance challenges in the Western USA: on top of relatively scarce water resources, the region has large urban areas, substantial agricultural activity, important ecological water needs, and numerous competing opinions about the competing value of these uses (Hanak et al. 2011; Ulibarri and Escobedo Garcia 2020). By focusing on a single region, we hold the underlying environmental and political context more constant than we would sampling plans from across the state. While water is perhaps more contested in the Central Valley than in other parts of California, we also anticipate that local agencies (the plan authors) are less willing to accept central control of water and therefore may embrace plans as a local solution.

To understand how plans are used, we pair the discourse content analysis with semi-structured, in-depth interviews with 15 water practitioners in the Central Valley. We used a purposive approach to sampling, inviting districts that had authored the plans we reviewed (Table 2). Interviewees represented urban water utilities $(n=9)$, irrigation districts $(n=2)$, and regional water authorities $(n=4)$; each agency 
Table 2 Documents analyzed

\begin{tabular}{lcc}
\hline Legislation & Guidance documents & Plans \\
\hline $\begin{array}{l}\text { Urban Water Management Planning Act of } \\
1983\end{array}$ & $\begin{array}{c}\text { 2015 Urban Water Management Plans Guide- } \\
\text { book for Urban Water Suppliers }\end{array}$ & $\begin{array}{c}\text { 20 Urban Water Management Plans (UWMPs), } \\
\text { e.g., San Juan Water District UWMP }\end{array}$ \\
$\begin{array}{l}\text { Regional Water Management Planning Act } \\
\text { of 2002 }\end{array}$ & $\begin{array}{c}\text { Integrated Regional Water Management } \\
\text { Proposition 84 and 1E November 2012 } \\
\text { Guidelines }\end{array}$ & $\begin{array}{c}\text { 4 Integrated Regional Water Management Plans } \\
\text { (IRWMPs), e.g., Southern Sierra IRWMP }\end{array}$ \\
Water Conservation Act of 2009 & A Guidebook to Assist Agricultural Water & 9 Agricultural Water Management Plans \\
& $\begin{array}{l}\text { Suppliers to Prepare a 2015 Agricultural } \\
\text { (AWMPs), e.g., Sacramento Valley AWMP }\end{array}$ \\
Wustainable Groundwater Management Act & Guidance Document for the Sustainable Man- \\
of 2015 & agement of Groundwater: GSP Annotated & e.g., North Kings Groundwater Sustainability \\
& Outline; Best Management Practices for the & Agency GSP \\
& Sustainable Management of Groundwater: & \\
& Sustainable Management Criteria &
\end{tabular}

was represented by a single interviewee. While we wanted to also understand the oversight agency's viewpoint, we were unsuccessful in securing an interview with DWR. Interviews lasted between 45 and $75 \mathrm{~min}$. The interviews covered numerous topics on water management, from specific innovations and approaches used, to factors that influence their decision-making, to challenges they face. For this paper, we focus on a subset of questions asking how practitioners used their district's plans, how frequently they were used, and whether and why they found the plans useful. Interviews were professionally transcribed and analyzed using an inductive coding approach in NVivo qualitative analysis software. Inductive coding allows for important themes to emerge from the data itself, allowing for analysis dimensions that a researcher did not anticipate before beginning the research (Corbin and Strauss 2008). Our interview coding identified categories of uses and rationales for why practitioners did (or did not) use the plans.

\section{Results}

\section{What goals underlie the requirement to write a plan?}

We first evaluate the rationale for using plans as a policy tool, as stated in the authorizing legislation. The UWMPA's goals are (1) for water suppliers to conduct long-term resource planning, (2) to inform the public of an urban water supplier's plans for long-term resource planning that ensures adequate water supplies for existing and future demands, and (following amendments under SB X7-7) (3) to establish water use targets to support a required statewide $20 \%$ reduction in urban water use (CWC [Calif. Water Code] $\$ 10,610.2$ ). As such, the main goal of the UWMPA is the production of a planning document (the UWMP) (CWC $\S 10,620$ ), making the question of why planning somewhat tautological. Additionally, as stated in both the legislation and the state produced urban water planning guidelines, planning is seen to be well-suited for ensuring supply in the event of drought (CWC $\S 10,631)$.

As a cross-jurisdictional watershed approach, the RWMPA had two main goals: (1) help purveyors, planners, landowners, and other stakeholders develop plans to better manage their water resources efficiently and (2) encourage regional collaboration $(\mathrm{CWC} \$ 10,540(\mathrm{a}))$. A major aspect of achieving these goals was through the creation of IRWMPs; however, unlike the other three statutes, RWMPA did not include mandatory planning requirements. In fact, the legislation explicitly states it does not obligate a local agency to fund the implementation of any project or program (CWC $\S 10,540(d))$. The use of plans was justified by noting that IRWMPs could address the protection and improvement of water supply reliability, including identifying feasible agricultural and urban water use efficiency strategies; considering drinking water quality of communities within the area of the plan; and protecting and improving water quality within the area of the plan. Additionally, regional water management groups could, but were not required, to coordinate their plans with other planning efforts such as groundwater, urban water, city and county, agricultural, and stormwater resources planning (CWC $\$ 10,540(\mathrm{a}))$.

The goals of the AWMPA center around water conservation (CWC $\$ 10,608.4)$. The key purpose of the law is to encourage agricultural water providers to implement conservation strategies, monitor water usage, and report data to DWR. ${ }^{1}$ To demonstrate a move toward conservation, the legislation required agricultural water suppliers to prepare and adopt AWMPs (CWC $\$ 10,826)$. Additionally, the AWMPA

\footnotetext{
${ }^{1} \mathrm{SB} \times 7-7$, the parent legislation of the AWMPA, includes regulations targeting urban water providers, but for this analysis, we focus only on the AWMPA subsection.
} 
Table 3 Summary of legislative goals and associated plan use types

\begin{tabular}{|c|c|c|c|}
\hline Legislation & Legislative goal(s) & Plan justification & Plan uses highlighted \\
\hline $\begin{array}{l}\text { Urban Water Management Planning } \\
\text { Act of } 1983\end{array}$ & $\begin{array}{l}\text { Conduct long-term resources plan- } \\
\text { ning and reduce urban water use }\end{array}$ & $\begin{array}{l}\text { Planning is best suited for ensuring } \\
\text { supply in the event of drought }\end{array}$ & Instrumental \\
\hline $\begin{array}{l}\text { Regional Water Management Plan- } \\
\text { ning Act of } 2002\end{array}$ & $\begin{array}{l}\text { Achieve effective water management } \\
\text { and encourage regional collabora- } \\
\text { tion }\end{array}$ & $\begin{array}{l}\text { Planning is an effective means to } \\
\text { maximize the quality and quantity } \\
\text { of water available to meet the state's } \\
\text { water needs by providing a frame- } \\
\text { work for local agencies to integrate } \\
\text { programs and projects that protect } \\
\text { and enhance regional water supplies }\end{array}$ & Instrumental, conceptual \\
\hline $\begin{array}{l}\text { Agricultural Water Management Plan- } \\
\text { ning Act of } 2009\end{array}$ & $\begin{array}{l}\text { Achieve agricultural water conserva- } \\
\text { tion }\end{array}$ & $\begin{array}{l}\text { Agricultural utilities should be } \\
\text { required to plan because urban utili- } \\
\text { ties have to }\end{array}$ & Instrumental, tactical \\
\hline $\begin{array}{l}\text { Sustainable Groundwater Manage- } \\
\text { ment Act of } 2015\end{array}$ & $\begin{array}{l}\text { Sustainably manage groundwater } \\
\text { through the creation of GSA and } \\
\text { GSPs }\end{array}$ & $\begin{array}{l}\text { Planning will provide information on } \\
\text { the amount of groundwater extrac- } \\
\text { tion, natural and artificial recharge, } \\
\text { and groundwater evaluations that } \\
\text { are critical for effective manage- } \\
\text { ment of groundwater }\end{array}$ & Conceptual \\
\hline
\end{tabular}

incentivized the creation of AWMPs by making agricultural water suppliers ineligible for a water grant or loan awarded or administered by the state unless the supplier complies with the requirements of the AWMPA, which includes the submission of an AWMP (CWC $\$ 10,608.56$ (b)). The primary rationale for requiring plans was that other water agencies (including agricultural agencies that receive water from the federal government) have to prepare plans: "Urban water districts are required to adopt water management plans... [and] Agricultural water suppliers that receive water from the federal Central Valley Project [CVP] are required by federal law to prepare and implement water conservation plans... [Therefore] Agricultural water suppliers [including those who do not receive CVP water] shall be required to prepare water management plans to achieve conservation of water" (CWC \$10,801).

The goal of SGMA was to give local and regional agencies the authority to sustainably manage groundwater through establishment of GSAs and creation and implementation of GSPs (CWC $\$ 10,720.1)$. The legislation does not provide an explicit justification for why planning, but planning was considered an important aspect of reaching sustainability (CWC $\$ 10,727)$ and was identified as critical to understanding water supplies in groundwater basins to support long-term sustainability (CWC \$10,720.1).

Overall, these four statutes looked to address pressing issues in water management planning, collaboration, conservation, and sustainability. Their specific rationales for requiring plans varied, from noting that plans are effective tools to share information and set priorities (instrumental and conceptual uses) to arguing that utilities should write plans because other organizations have to (tactical uses) (Table 3). Via plans, the statues also gave new authority to local agencies to manage a resource (SGMA), incentivize collaboration (RWMPA, SGMA), extend the time horizon of water management (UWMPA), and extend planning requirements to new types of utilities (conceptual uses). Overall, however, justification for the use of plans was brief.

\section{What goals are emphasized in guidance documents?}

We next review associated guidance documents to assess which features of the legislation the oversight agency (DWR) emphasizes and how they support water agencies in the process and content of plan writing. Overall, guidance documents for all four statutes focus on supporting direct implementation of the legislation but vary in the level of additional detail they provide. Most guidance focuses on the content of the plans, rather than the process of planning.

DWR published a guidebook to support urban water suppliers with the creation and adoption of their 2015 UWMPs (California Department of Water Resources 2016a). In this guide, DWR reviews requirements from California Water Code (CWC), offers suggestions on how to fulfill those legal requirements, and provides additional recommendations to support plan writing. The guidelines also provide an example of how to organize UWMPs in order to ensure that all requirements are included and a checklist of specific UWMP requirements, which UWMP preparers are requested to submit.

In many instances, the guidance document does not expand much beyond the legislative text regarding content requirements. For instance, one required element is "Demand Management Measures" (DMM). The CWC requires a narrative that includes descriptions of DMMs for metering, public education and outreach, and water 
conservation program coordination and staffing support (CWC $\$ 10,631$ (1)(B)). Beyond repeating the CWC description of the required narrative, DWR guidelines do not offer much guidance, simply stating that wholesalers should describe water conservation programs if they have them and that utilities should describe any innovative approaches to demand management.

The UWMPA also requires wholesalers and retail agencies to coordinate. When a water supplier relies upon a wholesale agency for a water supply, both the wholesaler and the supplier are required to provide each other with information regarding projected water supply and demand. Coordination with other agencies and the public is only required to the "extent practicable" (CWC \$10,620); urban water suppliers are "encouraged" to actively involve diverse social, cultural, and economic elements of the population within the service area prior to and during the preparation of the plan (CWC \$10,642). In discussing coordination, the guidelines focus on how to report coordination and what types of coordination is legally required. The guidance document provides various examples of tables that could serve as proof of coordination, which include reporting things like lists of stakeholders, lists of who received drafts of UWMPS, and lists of organizations that were notified of UWMP.

The DWR guidelines also suggest one process element that was not required under UWMPA: they recommend that water suppliers consider the extent to which they will become involved in regional planning processes before developing a UWMP, highlighting that regional planning could benefit regional water security.

The primary guidance for the IRWMPs is found in the IRWM Grant Program Guidelines for Prop 84 and 1E (California Department of Water Resources 2012), the key funding mechanisms for the IRWM program. The guidelines give an overview of the "IRWM Plan Standards," which they use to describe what must be in an IRWM Plan and what criteria would be used to evaluate Implementation Grant applications (applications for funding that individual water agencies within the IRWM region could apply for). There are 16 plan standards discussed in the guidance, which expand on the seven minimum requirements found in the legislation.

Additionally, the RWMPA has as a major goal the establishment of a collaborative watershed approach to water management. DWR's guidelines provide extensive guidance for Governance, Region Description, and to some extent Stakeholder Involvement and Coordination, the sections that most closely translate the collaborative goals of RWMPA. In the Governance section, plan writers are required to describe how their chosen form of governance ensures things like effective communication (both internal and external to the IRWM region), coordination with neighboring IRWM efforts and state and federal agencies, and the collaborative process(es) used to establish plan objectives.
The Stakeholder Involvement and Coordination sections include requirements to describe the process used to identify, inform, invite, and involve stakeholder groups in the IRWM process, including mechanisms and processes that have been or will be used to facilitate stakeholder involvement and communication during development and implementation of the IRWM Plan and identification of a process to coordinate water management projects and activities of participating local agencies and local stakeholders to avoid conflicts and take advantage of efficiencies (CWC §10,541.(e)(13)).

In preparation for the 2016 round of AWMPs, DWR's Division of Statewide Integrated Water Management Water Use and Efficiency Branch produced a guidebook to assist agricultural water suppliers in writing their AWMPs (California Department of Water Resources 2015). The guidebook includes an explanation as to how to use the guidebook, its objectives, a list of important deadlines for agricultural water suppliers, and a background on agricultural water management planning. The appendix includes worksheets and templates that agricultural water suppliers can use in preparing the AWMP. The guidebook makes it clear that while encouraged, agricultural water suppliers were not required to use the guidebook, supporting tools, nor the templates and worksheets.

The guidelines focus extensively on water supply quantification, with five pages outlining how agencies should account for how much water an agricultural supplier uses, where the supply comes from, and for what purposes the water is used. AWMPs must also include an analysis, based on available information, of the effect of climate change on future water supplies (CWC $\S 10,826(8)(\mathrm{c})$; the guidelines provide several examples of the way that climate change might affect water supplies or demand, but these are briefer than the guidance for water accounting.

Looking toward implementation, the AWMPA requires “...a report on which efficient water management practices have been implemented and are planned to be implemented, an estimate of the water use efficiency improvements that have occurred since the last report, and an estimate of the water use efficiency improvements estimated to occur five and 10 years in the future. If an agricultural water supplier determines that an efficient water management practice is not locally cost effective or technically feasible, the supplier shall submit information documenting that determination" (CWC $§ 10,608.48$ (d)). The guidelines state that agricultural water suppliers shall implement their AWMP according to the schedule set forth in the AWMP.

SGMA is accompanied by substantial guidance in comparison to the other three statues. Besides the much more detailed descriptions of the GSPs in the authorizing statutes, DWR produced seven different "Best Management Practices" guides and six additional guidance documents, as well as guides assisting GSAs in their GSP 
Table 4 Summary of guidance documents and associated plan use types

\begin{tabular}{llll}
\hline Plan type & Guidance document topics & Level of detail & Plan uses highlighted \\
\hline UWMP & Suggested plan structure, required content & Moderate & Instrumental, partly conceptual \\
IRWMP & Required and suggested standards, collaborative process & Moderate & Instrumental, conceptual \\
AWMP & Suggested content, suggested plan structure & Moderate & Instrumental \\
GSP & $\begin{array}{l}\text { Extensive guidance on planning process, required and suggested } \\
\text { content, plan structure }\end{array}$ & High & Instrumental, conceptual
\end{tabular}

submission process. This may in part be due to the monumental changes in groundwater management that occurred as a result of the passing of SGMA, as well as the need to support different agencies who were about to create a groundwater management plan for the first time.

For this paper, three guidance documents are most relevant. First, DWR produced a GSP Annotated Outline (California Department of Water Resources 2016b) and Preparation Checklist (California Department of Water Resources 2016c); DWR states that GSAs may use these documents to develop a GSP and determine if the GSP (or coordinated GSPs) meets the minimum requirements of the GSP Regulations and statutory provisions of SGMA. The GSP Annotated Outline shows an example of how chapters can be broken down in a GSP, an order in which the information could be presented, and a few bullet points outlining what information could be included in each chapter. This outline overviewed six chapters: Executive Summary and Introduction; Plan Area and Basin Setting; Basin Setting; Sustainable Management Criteria; Projects and Management Actions to Achieve Sustainability Goal; Plan Implementation; and References and Technical Studies.

The other guidance document that is relevant for this paper is the Best Management Practices for the Sustainable Management of Groundwater: Sustainable Management Criteria (California Department of Water Resources 2017a). This document was developed to describe activities, practices, and procedures for defining the sustainable management criteria required by the GSP Regulations. This document reviews SGMA requirements to define sustainability, preliminary activities, and set sustainable management criteria. The chapter that goes over how to set sustainable management criteria (SMCs) offered substantially more information than what was originally in the SGMA requirements for SMCs. The chapter reviews the six undesirable groundwater outcomes outlined in SGMA (e.g., reduction in storage, land subsidence), explains how to set minimum thresholds, explains how to set measurable objectives, and discusses the role of the sustainability goal.

Table 4 summarizes the topics covered by guidance documents and the types of plan uses they suggest.

\section{What does the written plan content emphasize?}

Overall, the plans reviewed very carefully conformed to minimum requirements from legislation or guidance documents. When DWR guidelines provided templates or a suggested order for content, these were followed meticulously. For instance, while the use of coordination templates was not required by the AWMPA, in all the AWMPs reviewed, the template was essentially copied and pasted (Fig. 1).

Likewise, almost all IRWMPs we reviewed included the 16 plan standards, even if it was a brief discussion. One IRWMP did not discuss all plan standards but did include the seven minimum requirements. The reviewed GSPs followed DWR's guidance meticulously, not just in order, but in adoption of specific scenarios (each of which was associated with specific thresholds and timelines for implementation).

However, the content of the plans suggests that authoring agencies wrote them to fulfill legislative requirements rather than to guide their policies or programs. In general, the plans reflected required elements, but almost never included suggested elements. While many UWMPs discussed public outreach or generally mentioned it, the plans did not offer substantive discussion nor proof of engagement. Often public outreach/engagement was discussed no further than saying the UWMPs were made available to the public for review and/or including lists of the public outreach materials. Many UWMPs included public outreach as a best management practice but presented only general explanations of how public outreach/engagement was conducted or was planned to be conducted. And none of the UWMPs incorporated a regional planning process (as recommended by DWR).

In some cases, plans provided even less information than requested. Even though AWMPs were required to include a climate change analysis, these analyses were often brief and general, with not much substantive information on how climate change would impact their supply. One plan stated, "If global climate change predictions indicating less precipitation as snow and more as rainfall are correct, then increased reservoir storage will be essential in the future to capture water for beneficial use" (Fresno Irrigation District 2016, p. 4 emphasis added). Likewise, the water shortage contingency plans in the UWMPs provided minimal information 
Worksheet 1. Summary of Coordination, Adoption, and Submittal Activities

\begin{tabular}{|c|c|c|c|c|c|c|}
\hline $\begin{array}{l}\text { Potential Interested } \\
\text { Parties } \\
\text { [Provide names(s)] }\end{array}$ & $\begin{array}{l}\text { Notified of } \\
\text { AWMP } \\
\text { Preparation }\end{array}$ & $\begin{array}{c}\text { Requested } \\
\text { Copy of } \\
\text { Draft } \\
\text { (Optional) }\end{array}$ & $\begin{array}{c}\text { Commented } \\
\text { on } \\
\text { Draft/Action } \\
\text { Taken by } \\
\text { Supplier } \\
\text { (Optional) }\end{array}$ & $\begin{array}{l}\text { Notified of } \\
\text { Public } \\
\text { Meetings }\end{array}$ & $\begin{array}{l}\text { Attended } \\
\text { Public } \\
\text { Meetings } \\
\text { (Optional) }\end{array}$ & $\begin{array}{c}\text { Copy of } \\
\text { Adopted } \\
\text { AWMPI } \\
\text { Amendment } \\
\text { Sent }\end{array}$ \\
\hline Local City(s) & [Insert Date] & & & & & [Insert Date] \\
\hline Local County(s) & [Insert Date] & & & & & [Insert Date] \\
\hline $\begin{array}{l}\text { Groundwater } \\
\text { Management Entity }\end{array}$ & & & & & & [Insert Date] \\
\hline $\begin{array}{l}\text { Urban Water } \\
\text { Supplier(s) }\end{array}$ & & & & & & [Insert Date] \\
\hline City or County Library & & & & & & [Insert Date] \\
\hline $\begin{array}{l}\text { Local Agency } \\
\text { Formation } \\
\text { Commission }\end{array}$ & & & & & & [Insert Date] \\
\hline DWR & & & & & & [Insert Date] \\
\hline $\begin{array}{l}\text { Local Newspaperl } \\
\text { Equivalent Process } \\
\text { [/dentify which] }\end{array}$ & & & & $\begin{array}{l}\text { [Insert } \\
\text { Dates] }\end{array}$ & & \\
\hline \multicolumn{7}{|l|}{$\begin{array}{l}\text { Other Local } \\
\text { government agency }\end{array}$} \\
\hline \multicolumn{7}{|l|}{ Other Special districts } \\
\hline \multicolumn{7}{|l|}{ Regional agency } \\
\hline \multicolumn{7}{|l|}{$\begin{array}{l}\text { Environmental citizen } \\
\text { group }\end{array}$} \\
\hline \multicolumn{7}{|l|}{ Land Use Agencies } \\
\hline Business group & & & & & & \\
\hline
\end{tabular}

Worksheet 1. Summary of Coordination, Adoption, and Submittal Activities

\begin{tabular}{|c|c|c|c|c|c|c|c|c|}
\hline Potential Interested Parties & $\begin{array}{c}\text { Notified of } \\
\text { Draft AWMP } \\
\text { and Public } \\
\text { Meeting }\end{array}$ & $\begin{array}{l}\text { Requested } \\
\text { Copy of } \\
\text { Draft AWMP }\end{array}$ & $\begin{array}{l}\text { Copy of } \\
\text { Adopted } \\
\text { AWMP } \\
\text { Sent }\end{array}$ & $\begin{array}{c}\text { Commented } \\
\text { on Draft } \\
\text { AWMP }\end{array}$ & $\begin{array}{l}\text { Attended } \\
\text { Public } \\
\text { Meeting }\end{array}$ & $\begin{array}{l}\text { Copy of } \\
\text { Revised } \\
\text { AWMP } \\
\text { Sent }\end{array}$ & $\begin{array}{c}\text { Revised } \\
\text { AWMP Public } \\
\text { Meeting } \\
\text { Notice }\end{array}$ & $\begin{array}{c}\text { Commented } \\
\text { on Revised } \\
\text { AWMP }\end{array}$ \\
\hline Seima Enterprise & $\begin{array}{l}4 / 29 / 15 \\
5 / 06 / 15 \\
\end{array}$ & & & & & & $\begin{array}{c}3 / 30 / 16 \\
4 / 6 / 16 \\
\end{array}$ & \\
\hline County of Fresno & & & & & & $3 / 24 / 16$ & & \\
\hline County of Kings & & & & & & $3 / 24 / 16$ & & \\
\hline County of Tulare & & & & & & $3 / 24 / 16$ & & \\
\hline City of Reedley & & $5 / 11 / 15$ & $5 / 12 / 15$ & $5 / 27 / 15$ & $5 / 12 / 15$ & $3 / 24 / 16$ & & \\
\hline City of Xingsburg & & & & & & $3 / 24 / 16$ & & \\
\hline City of Selma & & & & & & $3 / 24 / 16$ & & \\
\hline City of Fowler & & & & & & $3 / 24 / 16$ & & \\
\hline City of Sanger & & & & & & $3 / 24 / 16$ & & \\
\hline City of Parlier & & & & & & $3 / 24 / 16$ & & \\
\hline District Landowners/Water Users & $5 / 17 / 15$ & & & & & & $7 / 13 / 16$ & \\
\hline County Lbrary \& State Library & & & & & & $3 / 24 / 16$ & & \\
\hline Department of Water Resources & & & & & & $3 / 24 / 16$ & & \\
\hline
\end{tabular}

Fig. 1 Comparing the guideline template (top) to an AWMP (bottom) 
Table 5 Summary of plan content and associated plan use types

\begin{tabular}{|c|c|c|c|c|}
\hline Plan type & $\begin{array}{l}\text { Conformance with minimum } \\
\text { criteria }\end{array}$ & $\begin{array}{l}\text { Description of planning } \\
\text { process }\end{array}$ & Accuracy and implementability & Plan uses highlighted \\
\hline UWMP & $\begin{array}{l}\text { All plans include required } \\
\text { elements }\end{array}$ & $\begin{array}{l}\text { Minimal, checkbox for coor- } \\
\text { dination }\end{array}$ & $\begin{array}{l}\text { Variable level of detail, factual } \\
\text { discrepancies }\end{array}$ & Tactical, partly instrumental \\
\hline IRWMP & $\begin{array}{l}\text { All plans include required } \\
\text { elements, } 4 \text { of } 5 \text { include sug- } \\
\text { gested elements }\end{array}$ & $\begin{array}{l}4 \text { of } 5 \text { plans have extensive } \\
\text { discussion }\end{array}$ & Variable level of detail & Conceptual, partly instrumental \\
\hline AWMP & $\begin{array}{l}\text { All plans include required } \\
\text { elements }\end{array}$ & Minimal & $\begin{array}{l}\text { Minimal detail, factual discrep- } \\
\text { ancies }\end{array}$ & Tactical \\
\hline GSP & $\begin{array}{l}\text { All plans include required } \\
\text { elements }\end{array}$ & Variable & Variable level of detail & $\begin{array}{l}\text { Conceptual, partly instrumental, } \\
\text { tactical }\end{array}$ \\
\hline
\end{tabular}

on actual management practices to reduce drought impacts during prolonged periods of water shortages. In one UWMP, the agency did not include a drought contingency plan, stating that their dependence on groundwater meant they could pump unlimitedly, meaning they would not be impacted by drought (Quad Knopf, Inc. 2017).

The primary exception to plans appearing to only meet minimum guidelines was in quantifying water supplies. Most plans across all four types had extensive documentation of their water supplies, both projections of current and future use, as well as detailed information on where districts receive their supplies from. The legislation and guidelines offered substantive requirements around documenting water supplies, and this translated into detailed assessments in the plans themselves.

The second exception is the IRWMP's collaboration requirement, which was usually communicated with extensive chapters on Governance describing planning and coordination among different stakeholders. The Governance chapters offered detailed descriptions of how relevant stakeholders, such as various water districts, came to terms as to how they would collaborate by discussing their process of entering a Joint-Powers Agreements or Memorandums of Understanding, as well as their decision-making process and establishing committees and working groups. Additionally, some IRWMPs also included separate Coordination chapters in which they discussed topics such as relationship to local and state water planning, stakeholder involvement and coordination, and coordination with state and federal planning efforts.

Further evidence that plans were not intended to guide the authoring agencies' policies or programs is that plans would often list potential actions that could be taken but then say that they did not actually plan to take any of those actions because of a lack of funding. For example, in their review of water supplies, UWMPs often included all different types of water supplies available to urban water districts, such as recycled water, followed by statements like "There are no plans for a recycled water project in the City at this time" (Peters Engineering Group 2017, p. 35). There was also little evidence that water utilities intended to implement these plans. Often implementation chapters were no more than a few pages long and offered no more information than saying that the plans had been adopted and therefore were implemented.

Table 5 summarizes plan content, including conformance with legislation, emphasis on process, and implementability, and categorizes the plans according to the plan use typology.

\section{How are plans used?}

We lastly assess how the plans are used by the water utilities required to write them and what broader governance or political benefits they may provide. Our interviews with water practitioners reinforce the notion that the required plans have little implication for their day-to-day practices and management. There were many references to practitioners creating these plans because they were legally required: "We use the urban water management plans as a... planning tool just to comply with state law because we have to, but when a new development comes in, we're not pulling that out and looking at okay, did we account for that?"; "we do Urban Water Management Plans. Those are required every five years by law, so we have to do those." Many interviewees expressed these sentiments, stating that they create these plans mostly because they are state requirements. Interviews also did not indicate there was much that was done with these types of plans other than a reference for water budgets, with one interviewee stating "Do we really use this plan in our dayto-day work? No, we don't. Pretty much, it has stayed on the shelf." This is not to say, however, that plans as a whole were seen as useless. Several interviewees pointed to other types of plans, such as Water Master Plans, as being more practical and more closely related to management activities the organizations engage with.

While many interviewees did not report using the required plans on a regular basis or for management purposes, many found them useful for conceptual purposes: as accounting 
tools and for the planning process. Many stated several times that they were a helpful reference when thinking about water budgets: "I'd say it's great information..."; "it's more of a long-term planning document. It's a worse-case scenario of what would happen if we didn't have enough supply or if we had lower supplies than we expected"; "The Urban Water Management Plan could tell okay, look, at buildout the city would have potentially X amount of water available..." As overall water budgeting tools, interviewees found them helpful and effective.

Interviewees also highlighted the benefits of planning as a process. Many interviewees actively pointed to these plans as "good exercises." Many felt it was a practical step for long-term internal strategic planning and could have positive implications as a tool for collaboration, "I think with planning, so much benefit is actually creating the plan, going through that collaborative process." Much evidence of this can also be found in the creation of GSPs and IRWMPs. Requirements to involve a variety of stakeholders meant having organizations in the room, with overlapping jurisdictions, which may otherwise never have been in the same spaces.

Finally, some interviewees expressed frustration about repetition across the multiple plans they were required to produce. For instance, urban water utilities have to create water master plans, UWMPs, and participate in the creation of both IRWMPs and City/County General Plans. If they rely on groundwater, they are likely also part of a Groundwater Sustainability Agency. In many cases, they might also rely on federal water providers that require a separate set of plans. As noted by one interviewee, this creates an inefficiency: "We have a Bureau of Reclamation water management plan that we also have to put together and that's specifically for the Bureau of Reclamation which isn't necessarily the same as an Urban Water Management Plan, which was a struggle for us a little bit because we were doing two plans with a lot of the same information, but one was going to the federal government and one was going to the state."

As for how the plans are used by state agencies, we were unable to obtain interviews with DWR so instead rely on documents describing how submitted plans are reviewed by the state. SGMA was the only legislation that included language on how plans would be reviewed and evaluated once submitted. Per 23 CCR \$355.4, DWR shall evaluate an adopted GSP for compliance with ten requirements. These requirements include whether the assumptions, criteria, findings, and objectives are reasonable and supported by best available information/best available science and whether the projects and management actions are feasible, likely to prevent undesirable results, and ensure that the basin is operated within its sustainable yield.

The statutes and guidance documents for the other plan types do not describe how plans are evaluated by DWR.
However, submission of an UWMP, AWMP, and/or IRWMP is required for water utilities to be eligible for particular grants or loans administered by DWR. For instance, to access DWR funding, urban water suppliers must have a current UWMP on file that has been determined by DWR to address the requirements of the CWC. However, additional detail on what "addressing the requirements of the CWC" entails is not clear.

Additionally, the penalty for not submitting plans (or submitting subpar plans) is unclear. The fact that accepted plans fall short in some domains suggests that DWR may not be strictly enforcing the planning requirement. The exception is GSPs; DWR does notify submitting GSPs that their plans are deficient and require resubmission (Maven 2021). As for noncompletion, only $30 \%$ of eligible districts completed an AWMP, and an even smaller number completed their plans by the December 31, 2012, deadline; no evidence of negative repercussions (other than inability to access grant funding) is available. For other plans, data on submission rates are unavailable. A DWR report "Status of 2015 Urban Water Management Plans" (California Department of Water Resources 2017b) reviews compliance with UWMPA requirements, such as water use targets but neglects to address whether any UWMPs were not submitted or were rejected.

The regional approach used by the RWMPA does appear to be influencing state water management. According to the Water Education Foundation, since the passing of RWMPA, it has become a major component of the California Water Plan (Pitzer 2013). An excerpt from the 2005 Water Plan states "Integrated regional water management is the future of California because it will help regions diversify their water portfolio strategies and get the most from local, state and federal resources and funding" (California Department of Water Resources 2005). Additionally, in the 2009 Water Plan, a set of 13 objectives led by the expansion of IRWM was included (California Department of Water Resources 2009).

Table 6 summarizes evidence on how each plan type was used and benefits stated by authoring agencies and then categorizes the plans according to the plan use typology.

\section{Discussion}

This paper assessed the use of plans as a tool to influence water management in California. In evaluating why legislation prescribed plans (as opposed to other potential policy tools), we found minimal justification, with statutes either noting that planning is beneficial or justifying the action by noting that other water organizations are required to plan. However, all three goals (instrumental, conceptual, and tactical) were reflected to some degree in legislative justification. We found that the extent of guidance from 
Table 6 Summary of evidence for plan use and associated plan use types

\begin{tabular}{|c|c|c|c|}
\hline Plan type & Benefits stated by authoring agencies & Other evidence of use & Plan uses highlighted \\
\hline UWMP & Water accounting, meeting legislative mandate & Required for access to funding & Conceptual, tactical \\
\hline IRWMP & Regional collaboration, access to funding & $\begin{array}{l}\text { Collaborative approach adopted in other } \\
\text { state activities }\end{array}$ & Conceptual, tactical \\
\hline AWMP & Water accounting & No penalty for noncompletion & Tactical \\
\hline GSP & $\begin{array}{l}\text { Regional collaboration, water accounting, meeting legis- } \\
\text { lative mandate }\end{array}$ & Penalty for noncompletion & Conceptual, tactical \\
\hline
\end{tabular}

Table 7 Summary of plan use types by policy stage. Bolded uses are primary, uses in parentheses are secondary. Blue $=$ instrumental, purple $=$ conceptual, green $=$ tactical

\begin{tabular}{|l|l|l|l|l|}
\hline $\begin{array}{l}\text { Plan } \\
\text { Type }\end{array}$ & Legislative Goals & $\begin{array}{l}\text { Guidance } \\
\text { Documents }\end{array}$ & Plan Content & $\begin{array}{l}\text { Plan Use \& } \\
\text { Influence }\end{array}$ \\
\hline UWMP & Instrumental & $\begin{array}{l}\text { Instrumental, } \\
\text { (Conceptual) }\end{array}$ & $\begin{array}{l}\text { Tactical, } \\
\text { (Instrumental) }\end{array}$ & $\begin{array}{l}\text { Conceptual, } \\
\text { Tactical }\end{array}$ \\
\hline IRWMP & $\begin{array}{l}\text { Instrumental, } \\
\text { Conceptual }\end{array}$ & $\begin{array}{l}\text { Instrumental, } \\
\text { Conceptual }\end{array}$ & $\begin{array}{l}\text { Conceptual, } \\
\text { (Instrumental) }\end{array}$ & $\begin{array}{l}\text { Conceptual, } \\
\text { Tactical }\end{array}$ \\
\hline AWMP & $\begin{array}{l}\text { Instrumental, } \\
\text { Tactical }\end{array}$ & Instrumental & Tactical & Tactical \\
\hline GSP & Conceptual & $\begin{array}{l}\text { Instrumental, } \\
\text { Conceptual }\end{array}$ & $\begin{array}{l}\text { Conceptual, } \\
\text { (Instrumental), } \\
\text { (Tactical) }\end{array}$ & $\begin{array}{l}\text { Conceptual, } \\
\text { Tactical }\end{array}$ \\
\hline
\end{tabular}

state agencies varied across the plan types (despite them all being administered by DWR), with some guidance providing extensive details to support instrumental goals, others highlighting process features, and others providing minimal support beyond the initial legislation. As SGMA (the most recent statute) had the most detailed guidance, it appears that perhaps DWR is learning the value of guidance over time. Performance across plans in matching the statutory requirements also varied but mostly emphasized baseline conformance, with many plans reflecting minimum requirements but never adding additional details that would make the plans implementable. Reflecting existing planning literature (Shepherd 1998), we found that the plans themselves were rarely implemented directly or used by the authoring agencies. Interviewees expressed that many of these plans are produced because they are a legal requirement or are necessary to access funds but do not guide their management activities, emphasizing tactical over instrumental value. The exception was their use as water accounting tools-highlighting the conceptual value of data for routine decisions (Lindquist 1988).

While most of the statutes and guidance documents included goals related to the planning process (conceptual goals), with the exception of RWMA, they favored the product - the written plan-over the process of planning. They all detailed what topics and analysis a plan should include, and the final plans mostly reflected this guidance. However, while the statutes strongly encouraged authoring agencies to collaborate and/or coordinate, in many cases, "coordination" was reduced to simply checking a box that the plan was sent to another organization. In the case of RWMA, which had regional collaboration as a more explicit aim, the plans did suggest that authoring agencies did more than simply check a box, but other studies have found that the actual extent of collaboration varies substantially (Lubell and Lippert 2011; Conrad 2018; Hui et al. 2020).

Taken together, our results suggest that water planning requirements in California serve a variety of instrumental, conceptual, and tactical goals (Table 7). However, there is a disconnect wherein the legislation and guidance highlights instrumental and conceptual goals, whereas the written plans and their stated value shifts to tactical (with some conceptual) use. This shift, paired with the lack of repercussions for local water utilities failing to implement their plans, suggests that the ultimate value is primarily tactical: they enable legislators to do something for a pressing but politically contested policy problem but are more palatable than more direct policy tools. The history of SGMA supports this 
interpretation. While lawmakers had been aware of problems of groundwater overdraft for decades (and had required regulation in specific groundwater basins), it was not until an extreme drought in the mid-2010s that there was enough political will for the administration and legislature to act. Input from coalitions of water agencies emphasized that regulation should occur locally, with the state as a "backstop" for enforcement, and resulted in regulation with a fairly broad definition of sustainability to be refined for each local basin (Leahy 2015; Dennis et al. 2020). There was also substantial pushback to SGMA from the California Farm Bureau and Central Valley legislators (Leahy 2015), and many of the local basins struggled to include diverse voices in decision-making (Dobbin 2020; Méndez-Barrientos et al. 2020). While many laud SGMA for its innovation in multilevel governance, a concern is whether it will perform as well as a direct mandate to restrict pumping (Nelson and Perrone 2016; Roberts et al. 2021).

As for whether these plans serve the conceptual goal of learning and reflection, the plans we reviewed are all updated on 5-year cycles, creating an opportunity for iteration, addition of new concerns, and adoption of best practices across multiple organizations. However, none of the documents or interviews suggests that this is happening for local agencies. Water agencies update the plan because it is required, but the plans do not fundamentally change how they manage water. Additionally, the continual use of plans as a policy tool may actually be creating a burden for local agencies. Each new law stacks on top of existing planning requirements, but does not remove any previous laws; this creates an instance of institutional layering (Heijden 2011). Over time, it becomes redundant for the agencies to produce all of these documents; the marginal benefit of each new plan to the agency is minimal. That said, there may be a benefit of learning for the state. California water management has a high degree of fragmentation (Pincetl et al. 2016), with substantial activity occurring at the local level. As hundreds or thousands of different entities are involved, having local agencies produce plans in a standardized format could allow the state to systematically digest what is going on.

\section{Conclusion}

This research aimed to shed light on the use of plans within a larger policy ecosystem. While the planning literature has a long history evaluating the quality of plans, when used as a regulatory requirement, plans become a policy tool-and they are widely used in this regard. In addition to developing a new typology for evaluating plan use, our paper uniquely evaluates the content and use of plans (the more traditional domain of plan quality evaluation) and the legislative goals underlying the requirement to write plans. By understanding why policymakers require local agencies to write plans, how they support local agencies to write plans, and what purposes the plans serve creates a more holistic understanding of how governments regulate the environment.

In the context of California's Central Valley, we found that legislators turn to plans to support a mixture of instrumental, conceptual, and tactical goals but that the plans themselves (and the way they are used by authoring agencies) primarily serve conceptual and tactical uses, highlighting a disjoint between legislative goals and plan uses. Importantly, water management in the Central Valley is unique in many ways. It is highly politicized, with a vocal agricultural lobby holding the most senior water rights. In this context, legislators may be less willing to impose more direct regulations for fear of opposition, leading to more frequent use of plans. Local organizations representing the farming community (especially irrigation districts and groundwater sustainability agencies) may be more willing to visibly oppose external requirements, leading to the more tactically oriented plans. Additionally, while all federalist systems have power dynamics between higher and lower levels of government, California is a home rule state, meaning that local jurisdictions have a high degree of self-governing authority and local independence is particularly valued. This may make local entities less willing to conform with external mandates than may be present in other jurisdictions.

It is also important to note that we do not assess the full scope of water management policies in California. These plans are only one of several tools that state agencies use to influence local water management. For instance, state agencies also provide funding and sometimes require short-term decreases in demand. However, the planning requirements assessed here are a central tool, as direct regulations are less common (especially for agricultural water use). Additionally, we do not assess whether the plans are used by other organizations (e.g., by the state or nonprofits for monitoring purposes).

Each of these limitations suggests important avenues for future research. Exploring the full suite of water policy tools in proposed legislation would show what tools were considered besides plans and shed light on why legislators ultimately opted to require plans. Interviewing a broader set of water-related stakeholders would potentially uncover additional values the plans provide beyond the agencies who author them. Lastly, applying the instrumental, symbolic, and tactical use typology to plans in other sectors and jurisdictions would develop a broader theory of how plans are used in environmental governance.

Author contribution Study conception and design, NEG and NU; data collection, NEG; analysis and interpretation of the results, NEG and NU; draft manuscript preparation, NEG and NU; review and editing, NU. 
Funding This research was funded by the University of California Research Initiatives Award LFR-18-548316.

Availability of data and material All statutes, legislative guidance, and plans are publicly available (as referenced in the text). Interview data are protected by human subjects and cannot be shared.

Code availability Not applicable.

\section{Declarations}

Conflict of interest The authors declare no competing interests.

Open Access This article is licensed under a Creative Commons Attribution 4.0 International License, which permits use, sharing, adaptation, distribution and reproduction in any medium or format, as long as you give appropriate credit to the original author(s) and the source, provide a link to the Creative Commons licence, and indicate if changes were made. The images or other third party material in this article are included in the article's Creative Commons licence, unless indicated otherwise in a credit line to the material. If material is not included in the article's Creative Commons licence and your intended use is not permitted by statutory regulation or exceeds the permitted use, you will need to obtain permission directly from the copyright holder. To view a copy of this licence, visit http://creativecommons.org/licenses/by/4.0/.

\section{References}

Amara N, Ouimet M, Landry R (2004) New evidence on instrumental, conceptual, and symbolic utilization of university research in government agencies. Sci Commun 26:75-106

Andersson KP, Ostrom E (2008) Analyzing decentralized resource regimes from a polycentric perspective. Policy Sci 41:71-93

Berke P, Godschalk D (2009) Searching for the good plan: a metaanalysis of plan quality studies. J Plan Lit 23:227-240

Berke P, Backhurst M, Day M et al (2006) What makes plan implementation successful? An evaluation of local plans and implementation practices in New Zealand. Environ Plann B Plann Des 33:581-600

Beyer JM (1997) Research utilization: bridging a cultural gap between communities. J Manag Inq 6:17-22

Brody SD (2003) Are we learning to make better plans?: a longitudinal analysis of plan quality associated with natural hazards. J Plan Educ Res 23:191-201

Bunnell G, Jepson EJ (2011) The effect of mandated planning on plan quality. J Am Plann Assoc 77:338-353

California Department of Water Resources (2005) California water plan update 2005: a framework for action: public review draft. Department of Water Resources

California Department of Water Resources (2009) California water plan update 2009. State of California California Natural Resources Agency

California Department of Water Resources (2012) Guidelines: integrated regional water management proposition 84 and 1E. California Department of Water Resources

California Department of Water Resources (2015) A guidebook to assist agricultural water suppliers to prepare a 2015 agricultural water management plan. California Department of Water Resources
California Department of Water Resources (2016a) 2015 urban water management plans: guidebook for urban water suppliers. California Department of Water Resources

California Department of Water Resources (2016b) Guidance document for the sustainable management of groundwater: groundwater sustainability plan (GSP) annotated outline. California Department of Water Resources

California Department of Water Resources (2016c) Guidance document for the sustainable management of groundwater: preparation checklist for GSP submittal. California Department of Water Resources

California Department of Water Resources (2017a) Best management practices for the sustainable management of groundwater: sustainable management criteria. California Department of Water Resources

California Department of Water Resources (2017b) Status of 2015 urban water management plans. California Department of Water Resources

Conrad E (2018) Bridging the hierarchical and collaborative divide: the role of network managers in scaling up a network approach to water governance in California. Policy Polit 43:349-366

Corbin J, Strauss A (2008) Basics of qualitative research (3rd ed.): techniques and procedures for developing grounded theory. SAGE Publications

Cravens AE, McEvoy J, Zoanni D et al (2021) Integrating ecological impacts: perspectives on drought in the Upper Missouri Headwaters, Montana, United States. Weather, Climate, and Society 13:363-376

Dennis EM, Blomquist W, Milman A, Moran T (2020) Path dependence, evolution of a mandate and the road to statewide sustainable groundwater management. Soc Nat Resour 33:1542-1554

Dobbin KB (2020) "Good luck fixing the problem": small low-income community participation in collaborative groundwater governance and implications for drinking water source protection. Soc Nat Resour 33:1468-1485

Dunn WN (2017) Structuring policy problems. Public Policy Analysis: An Integrated Approach. Routledge, New York, pp 68-117

Feinberg DS, Ryan CM (2020) Evaluating the quality and implementation of hazard mitigation plans in coastal Washington State. Nat Hazards Rev 21:04020013

Flyvbjerg B (2006) Five misunderstandings about case-study research. Qual Inq 12:219-245

Forester J (1980) Critical theory and planning practice. J Am Plann Assoc 46:275-286

Fresno Irrigation District (2016) CA DWR agricultural water management plan. Fresno Irrigation District

Gilligan JM, Vandenbergh MP (2014) Accounting for political feasibility in climate instrument choice. Virginia Environmental Law Journal 32:1-26

Hanak E, Lund J, Dinar A, et al (2011) Managing California's water: from conflict to reconciliation. Public Policy Instit. of CA

Hopkins LD (2001) Urban development: the logic of making plans. Island Press, Washington, DC

Hopkins LD, Knaap G-J (2018) Autonomous planning: using plans as signals. Plan Theory 17:274-295

Horney J, Nguyen M, Salvesen D et al (2017) Assessing the quality of rural hazard mitigation plans in the southeastern United States. J Plan Educ Res 37:56-65

Hui I, Ulibarri N, Cain B (2020) Patterns of participation and representation in a regional water collaboration. Policy Stud J 48:754-781

Innes JE, Booher DE (2003) The impact of collaborative planning on governance capacity. University of California, Berkeley, Institute of Urban and Regional Development

Keohane NO, Revesz RL, Stavins RN (1996) The positive political economy of instrument choice in environmental policy. Research 
Programs, John F. Kennedy School of Government, Harvard University

Kinzer K (2018) How can we help? An exploration of the public's role in overcoming barriers to urban sustainability plan implementation. Sustain Cities Soc 39:719-728

Laurian L, Day M, Backhurst M et al (2004) What drives plan implementation? Plans, planning agencies and developers. J Environ Planning Manage 47:555-577

Leahy TC (2015) Desperate times call for sensible measures: the making of the California Sustainable Groundwater Management Act. Golden Gate U Envtl LJ

Lindquist EA (1988) What do decision models tell us about information use? Knowledge in Society 1:86-111

Lubell M, Lippert L (2011) Integrated regional water management: a study of collaboration or water politics-as-usual in California, USA. Int Rev Adm Sci 77:76-100

Maven (2021) This just in ... DWR releases second round of assessments of groundwater sustainability plans. In: Maven's Notebook. https://mavensnotebook.com/2021/11/18/this-just-in-dwr-relea ses-second-round-of-assessments-of-groundwater-sustainabilityplans/. Accessed 19 Nov 2021

Méndez-Barrientos LE, DeVincentis A, Rudnick J et al (2020) Farmer participation and institutional capture in common-pool resource governance reforms. The Case of Groundwater Management in California. Soc Nat Resour 33:1486-1507

Nelson RL, Perrone D (2016) Local groundwater withdrawal permitting laws in the south-western U.S.: California in comparative context. Ground Water 54:747-753

Neuman M (1998) Does planning need the plan? J Am Plann Assoc 64:208-220

Norton RK (2005) More and better local planning: state-mandated local planning in coastal North Carolina. J Am Plann Assoc 71:55-71

Ostrom V (1999) Polycentricity and local public economies. In: McGinnis MD (ed) Polycentricity and local public economies. University of Michigan Press, Ann Arbor, pp 52-74

Ostrom E (2010) Beyond markets and states: polycentric governance of complex economic systems. American Economic Review 100:641-672

Peters Engineering Group (2017) City of Kingsburg urban water management plan. City of Kingsburg

Pincetl S, Porse E, Cheng D (2016) Fragmented flows: water supply in Los Angeles county. Environ Manage 58:208-222
Pitzer G (2013) Layperson's guide to integrated regional water management. Water Education Foundation

Preston BL, Westaway RM, Yuen EJ (2011) Climate adaptation planning in practice: an evaluation of adaptation plans from three developed nations. Mitig Adapt Strat Glob Change 16:407-438

Quad Knopf, Inc. (2017) City of Lemoore 2015 urban water management plan. City of Lemoore

Randolph J (2011) Environmental land use planning and management, 2nd edn. Island Press

Roberts M, Milman A, Blomquist W (2021) The sustainable groundwater management act (SGMA): California's prescription for common challenges of groundwater governance. Water Resilience. Springer International Publishing, Cham, pp 41-63

Scott TA, Ulibarri N, Scott RP (2020) Stakeholder involvement in collaborative regulatory processes: using automated coding to track attendance and actions. Regulation \& Governance 14:219-237

Shepherd A (1998) Drought contingency planning: evaluating the effectiveness of plans. J Water Resour Plan Manag 124:246-251

Siders AR (2017) A role for strategies in urban climate change adaptation planning: lessons from London. Reg Environ Change 17:1801-1810

Taylor C, Pollard S, Rocks S, Angus A (2012) Selecting policy instruments for better environmental regulation: a critique and future research agenda. Environ Policy Gov 22:268-292

Ulibarri N (2015) Tracing process to performance of collaborative governance: a comparative case study of federal hydropower licensing. Policy Stud J 43:283-308

Ulibarri N, Escobedo Garcia N (2020) Comparing complexity in watershed governance: the case of California. Water 12:766

Ulibarri N, Escobedo Garcia N, Nelson RL, et al (2021) Assessing the feasibility of managed aquifer recharge in California. Water Resources Research 57.: https://doi.org/10.1029/2020wr029292

van der Heijden J (2011) Institutional layering: a review of the use of the concept. Politics 31:9-18

Vogel D (2018) California Greenin': how the Golden State became an environmental leader. Princeton University Press

Weiss CH (1979) The many meanings of research utilization. Public Adm Rev 39:426-431

Woodruff SC, Stults M (2016) Numerous strategies but limited implementation guidance in US local adaptation plans. Nat Clim Chang 6:796-802 